\title{
Development and validation of the patient evaluation scale (PES) for primary health care in Nigeria
}

\author{
Daprim S. Ogaji ${ }^{1,2}$, Sally Giles ${ }^{3}$, Gavin Daker-White ${ }^{3}$ and Peter Bower ${ }^{1}$ \\ ${ }^{1}$ NIHR School for Primary Care Research, Centre for Primary Care, Institute of Population Health, Manchester Academic \\ Health Science Centre, University of Manchester, Manchester, UK \\ ${ }^{2}$ Department of Preventive and Social Medicine, University of Port Harcourt, Nigeria, Choba, Rivers State \\ ${ }^{3}$ NIHR Greater Manchester Primary Care Patient Safety Translational Research Centre, University of Manchester, \\ Manchester, UK
}

\begin{abstract}
Background: Questionnaires developed for patient evaluation of the quality of primary care are often focussed on primary care systems in developed countries. Aim: To report the development and validation of the patient evaluation scale (PES) designed for use in the Nigerian primary health care context. Methods: An iterative process was used to develop and validate the questionnaire using patients attending 28 primary health centres across eight states in Nigeria. The development involved literature review, patient interviews, expert reviews, cognitive testing with patients and waves of quantitative cross-sectional surveys. The questionnaire's content validity, internal structures, acceptability, reliability and construct validity are reported. Findings: The full and shortened version of PES with 27 and 18 items, respectively, were developed through these process. The low item non-response from the serial cross-sectional surveys depicts questionnaire's acceptability among the local population. PES-short form (SF) has Cronbach's $\alpha$ of 0.87 and three domains (codenamed 'facility', 'organisation' and 'health care') with Cronbach's $\alpha$ s of $0.78,0.79$ and 0.81 , respectively. Items in the multi-dimensional questionnaire demonstrated adequate convergent and discriminant properties. PES-SF scores show significant positive correlation with scores of the full PES and also discriminated population groups in support of a priori hypotheses. Conclusion: The PES and PES-SF contain items that are relevant to the needs of patients in Nigeria. The good measurement properties of the questionnaire demonstrates its potential usefulness for patient-focussed quality improvement activities in Nigeria. There is still need to translate these questionnaires into major languages in Nigeria and assess their validity against external quality criteria.
\end{abstract}

Key words: Nigeria; patient evaluation scale; PES; primary health care; questionnaire development

Received 5 February 2016; revised 8 June 2016; accepted 4 July 2016; first published online 3 October 2016

Correspondence to: Dr Daprim S. Ogaji, NIHR School for Primary Care Research, Centre for Primary Care, Institute of Population Health, Manchester Academic Health Science Centre, University of Manchester, Suite $9,6^{\text {th }}$ Floor, Williamson Building, Oxford Road, University of Manchester, Manchester M13 9PL, UK. Email: daprim.ogaji@postgrad. manchester.ac.uk

\section{Introduction}

Primary health care (PHC) is the first point of contact to formal health care for the majority of the world's populace and also a key strategy for achieving health in most countries of the world 
(World Health Organization, 1978; Starfield, 1998; Starfield et al., 2005). In Nigeria, PHC centres constitute about $90 \%$ of formal health facilities and is the source of health care services to the majority of the populace, especially in rural areas (FMOH, Nigeria, 2012a). PHC provides promotive, preventive, curative and rehabilitative services through community health practitioners (community health extension workers and community health officers), nurses, midwives or doctors who work in the different structural and functional grades of health centres (FMOH, Nigeria, 2012b). The development of PHC is a key strategy in strengthening Nigeria's health system. In this regard, stakeholders recognise the need to improve community participation and ownership as one of its eight priority goals under the national strategic health development plan (FMOH, Nigeria, 2010). While this would ensure that health services are more patient friendly and socially relevant to the population (Van Lerberghe, 2008), the involvement of patients and the community in the planning, development and management of PHC services is known to result in improving responsiveness, utilisation, quality, health outcomes and sustainability of PHC (Crawford et al., 2002; FMOH, Nigeria, 2005; 2010).

Essentially, patients' participation in health care can be achieved through voluntary set-ups such as health consumers' groups or by giving special attention to patients' views during quality improvement (World Health Organization, 2006). For the latter, self or interviewer-administered questionnaires are commonly used to elicit feedback from patients after an encounter with PHC services (Wensing and Elwyn, 2002). These questionnaires are either developed through more extensive processes that are heavily dependent on patients or shorter processes that rely on subject experts (Fitzpatric et al., 1998; Wensing and Elwyn, 2002; Streiner and Norman, 2008). Irrespective of the above, draft items can be generated through inductive, deductive or a rational combination of both approaches (Hinkin, 1998; Streiner and Norman, 2008). These are subjected to further refinement, and possible psychometric validation to determine important measurement properties such as the internal structures, reliability and validity of these questionnaires (Hinkin, 1998; Streiner and Norman, 2008).
Despite progress in the development and use of valid and reliable questionnaires for assessing patient experiences of PHC in many settings, only a few have reference to settings in Sub-Saharan Africa (Haddad et al., 1998; Baltussen et al., 2002; Webster et al., 2011). Regrettable, no questionnaire had been developed or validated for patient evaluation of PHC in Nigeria. Furthermore, there are difficulties associated with the wholesome transfer of questionnaires across sociocultural and practice settings. These could arise from faulty translations, irrelevant contents or poor resolution of semantic issues across cultures. Fielding a battery of contextually relevant items in a questionnaire intended for use by patients is necessary to drive patient-focussed quality improvement, and ultimately ensure that PHC services produce better outcomes (Van Lerberghe, 2008). These arguments reinforce the need to develop an appropriate measure for assessing the performance and also drive reforms in service delivery in the Nigerian PHC setting. Patient involvement in all phases of this questionnaire development would enhance its potential utility in making PHC services more socially relevant to present needs of the patients and responsive to local practice context within a rapidly changing world.

This research is thus aimed at using established guidelines to develop a valid and reliable measure for patient evaluation of PHC in the Nigerian setting.

\section{Methods}

\section{Setting}

Nigeria is constitutionally subdivided into States, Local Government Areas, and Wards. Nonetheless, the six geopolitical zones (three each in the north and south of Nigeria) have become major divisions in modern Nigeria as they reflect greater homogeneity in culture, religion and ethnolinguistic groups (Figure 1). The population has an equal male to female ratio, an annual growth rate of $3.2 \%$ and life expectancy at birth of 52 years (National Population Commission, 2006; National Planning Commission/ICF International, 2014). The provision of formal health care to Nigeria's diverse geographic, linguistic, ethnic and religious constituents are through primary, secondary and tertiary facilities that are operated as public or private institutions. Primary health 


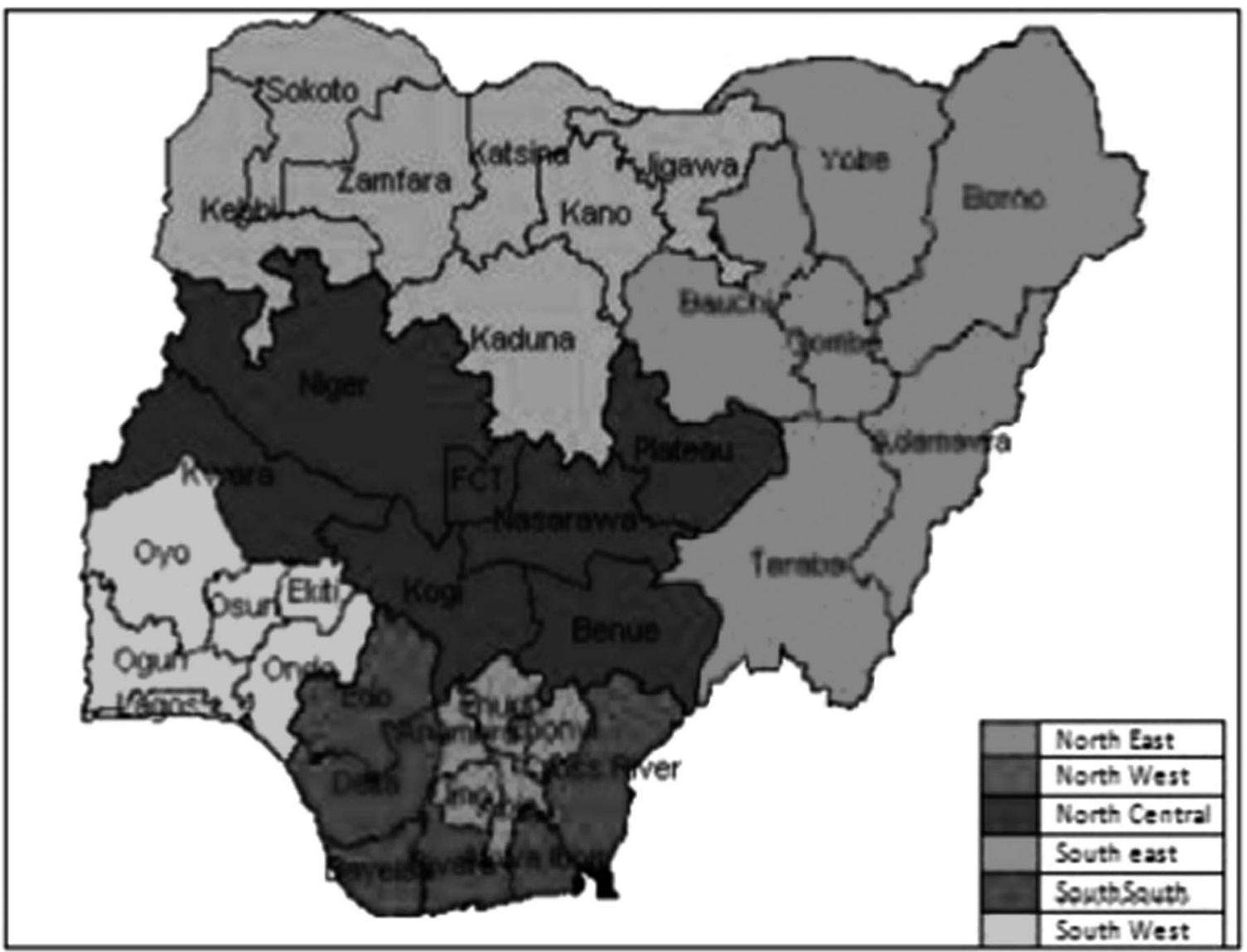

Figure 1 Map of Nigeria showing its 36 states, the federal capital territory and the geographical zones

centres are located in a wide spectrum of developmental setting including hard-to-reach, rural, semi-urban and urban. Care recipients make the decision on particular health facility to attend and undertake initial visits often without prior appointment. Payment for these services is predominantly out-of-pocket at the point of access as only $3 \%$ of the population, including $<2 \%$ of women aged 15-49 years enrolled in pre-payment plan (World Health Organization, 2012; Lagomarsino et al., 2012; National Planning Commission/ICF International, 2014).

\section{Development}

A multi-phase, mixed methods research was used in the development of the full and shortened forms of patient evaluation scale (PES). The iterative development involving series of independent research and subsequent revisions were used in the generation of items, further refinement and validation of the questionnaire (Figure 2) as summarised below.

\section{Phase 1: item generation}

Items were generated from the review of relevant literature and content analysis of 47 semi-structured interviews with $\mathrm{PHC}$ patients. We undertook a systematic review of studies on patients' views of PHC in Sub-Saharan African (Ogaji et al., 2015) and a second review of measures developed for patient evaluation of PHC globally. Studies were identified through systematic searches of Primary Health Care Research \& Development 2017; 18: 161-182 


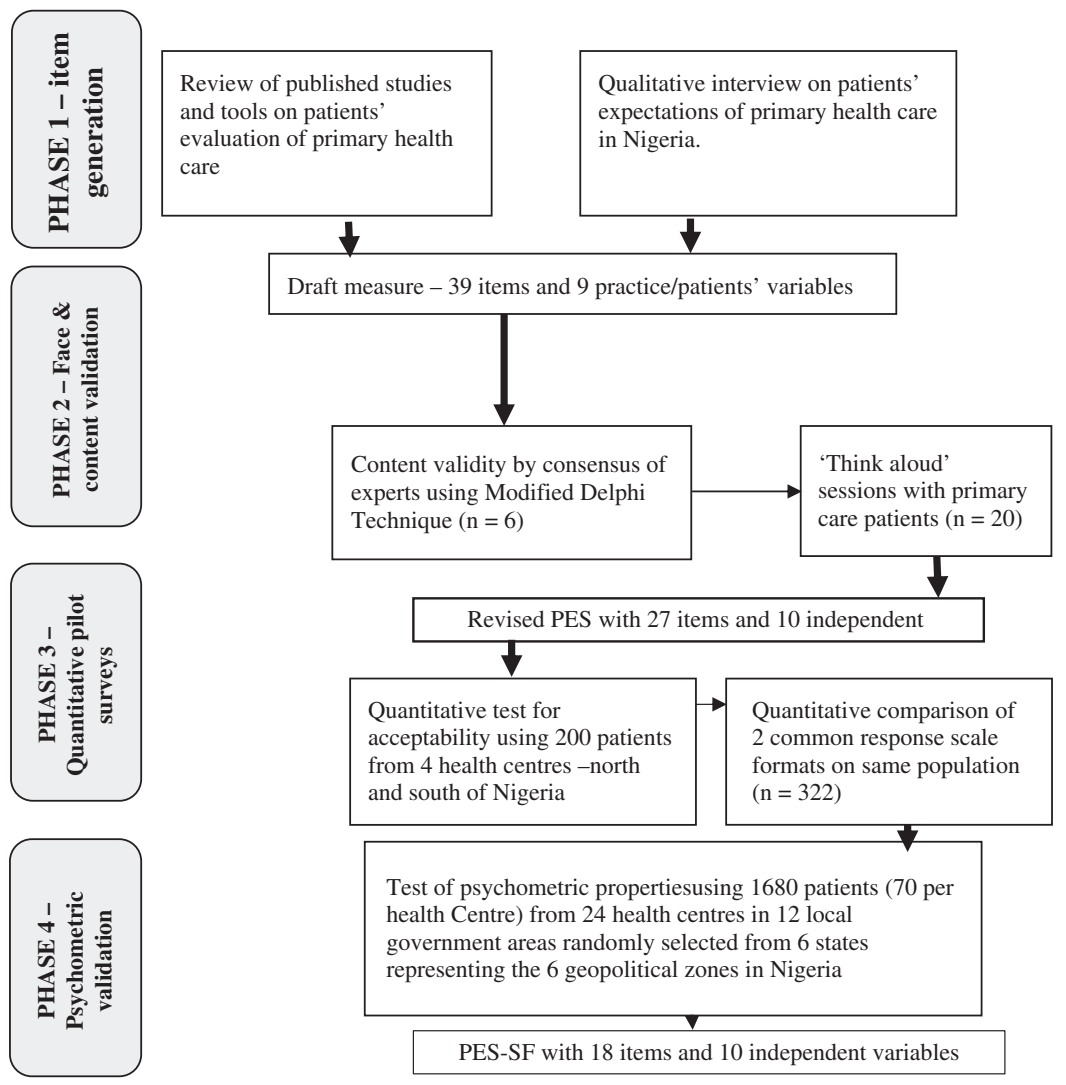

Figure 2 Phases in the development of the patient evaluation scale (PES). SF = short form.

Medline, CINAHL Plus, EMBASE and PsycINFO databases.

The appropriateness, acceptability and measurement properties of identified measures were evaluated based on recommended criteria (Fitzpatric et al., 1998; Bowling, 2014). The adapted checklist used in the assessment of these measures include the following:

(a) Are contents relevant to Nigeria cultural and practice setting?

(b) Are contents truly patient-based?

(c) Will the use of the instrument cause a high burden to patients and administrators?

(d) Has the instrument been validated for use in Nigeria?

(e) Has the instrument been validated for use in Sub-Saharan Africa?

(f) Can the instrument measure the structureprocess-outcome dimensions of quality? (g) Are reports on reliabilities of all scales adequate?

(h) Are reports on indices for assessing validity adequate?

The qualitative interviews explored the expectations of PHC patients and uncover items that could be used as scales in a questionnaire to assess patient experience of PHC in Nigeria. Maximum variation technique was used to purposefully recruit 47 patients based on the region of the country they live in (north or south), their gender, age (young, middle age and elderly) and health needs (curative or preventative services). Interview participants were visitors to four PHCs in Rivers State and the Federal Capital Territory in the southern and northern regions of Nigeria, respectively (Figure 1). Eligible interviewees were recruited from the stream of patients that visit these health centres. The sampling technique was 
not intended to achieve representativeness through equal probabilities but to ensure that the views of a wide range of PHC visitors are captured during the interviews. The verbatim transcripts of voice recordings and researcher's annotations were analysed by content analysis and the coded responses from this analysis were grouped into concepts and categories.

\section{Phase 2: face and content validity}

Subject experts and patients are often involved during the face and content validation of questionnaires (Fitzpatric et al., 1998; Streiner and Norman, 2008). While face validity ensures that items measure what they were supposed to, content validity assures that the new questionnaire contains sufficient sample of items that are needed to measure the construct of interest (Polit and Beck, 2006; Streiner and Norman, 2008).

Face and content validation by experts. The involvement of experts in the quantitative and qualitative review of the content, style and clarity of items in a questionnaire is a common practice (Grant and Davis, 1997; Polit and Beck, 2006; Campbell et al., 2009; Hernan et al., 2015). The content validation of this questionnaire by local experts was through a modified Delphi technique. The process involved an initial quantitative rating and estimation of some agreement indices among six PHC experts with academic (two), practice (two) and policy (two) backgrounds, and then a qualitative examination of the remaining items.

The tasks of these experts were

(i) To rate each of the included items in the draft questionnaire on a four-point relevance scale (1 - not relevant, 2 - somewhat relevant, 3 - quite relevant, 4 - very relevant). Two forms of agreement were then calculated from this process:

(a) The inter-rater proportional agreement was calculated as the item-level content validity index (i-CVI) which gave the proportion of convergence rating of 3 or 4 on any item. The scale-level content validity index (s-CVI) represented the average proportion of all items rated 3 or 4 by these experts (Polit and Beck, 2006). Items with i-CVI $\geqslant 0.78$ were considered quantitatively valid and relevant in the questionnaire and so were retained.
An $\mathrm{s}-\mathrm{CVI} \geqslant 0.8$ shows that the questionnaire contains an adequate sample of items needed to measure the latent construct (Lynn, 1986; Polit and Beck, 2006; Yaghmale, 2003).

(b) The intra-class correlation coefficient (ICC) for absolute agreement among multiple raters was used to confirm that the calculated interrater proportional agreement was higher than what should be expected by chance (Streiner and Norman, 2008). The ICC is a more accurate measure of agreement than the generalised $\kappa$ coefficients where observations are beyond the simple $2 \times 2$ agreement (Streiner and Norman, 2008).

In addition to the quantitative assessment of the content validity of the items, experts also ensured that items were clear, comprehensive and feasible for patients' use. The conclusion of the activities of these experts made it easy to operationalise the final set of items in the questionnaire for patients' use.

Think-aloud session with patients. The thinkaloud' approach with PHC patients was found suitable to 'road test' and further revise the questionnaire. In all, 20 adult patients visiting the Aluu Health Centre in Rivers State were consecutively given copies of the questionnaire while they were with the researcher. They were instructed to verbalise their thoughts on the clarity, appropriateness and comprehensibility of all the items and instructions in the questionnaire.

\section{Phase 3: quantitative pilot surveys}

Two consecutive waves of cross-sectional surveys were used to determine the questionnaire's acceptability across population groups and a more appropriate item response format as described below.

Testing questionnaire's acceptability. Survey involved 200 consecutive regular patients recruited from the four centres in the north and south of Nigeria where the qualitative interviews were earlier conducted. Acceptability was assessed across groups using indices such as

- response rate (proportion of sampled respondents that returned the questionnaire)

- item non-response rate (proportion of individual items in the questionnaire omitted by respondents) 
- endorsement frequencies (distribution of responses across the various response options)

- distribution characteristics of the scores (items mean scores, standard deviation, skewness, kurtosis and range)

- floor effect (proportion of respondents that endorsed the lowest response option) and

- ceiling effects (proportion of respondents that endorsed the highest response option) (Streiner and Norman, 2008).

Items with $>10 \%$ missing data or an uneven distribution of responses across the various response categories were further revised.

Testing response formats. The performance of two response formats was tested during the administration of questionnaire variants in sequence to 322 patients attending Aluu Primary Health Centre, Rivers State. Response formats were either five-point Likert-type response format ('strongly disagree', 'disagree', 'neither agree nor disagree', 'agree' and 'strongly agree') or fivepoint adjectival response format ('poor', 'fair', 'good', 'very good' and 'excellent'). The outcomes were response rate, missing items, questionnaire scores, time of completion and ease of patients' completion of the questionnaire (graded on 1-7 scale). The performance of these response formats was compared using the

- The standardised mean difference (SMD) of continuous measures such as item scores, time of completion and patient grading of the questionnaire.

- The odds ratios (OR) of proportions such as items' response rates and proportionate endorsement of floor and ceiling options.

\section{Phase 4: psychometric validation}

Although a minimum of 300 subjects are recommended for either exploratory or confirmatory factor analysis (Comrey and Lee, 2013), using larger sample size improves the chances of the estimates of the standard errors and factor loading being a true reflection of the actual population values (Hinkin, 1998). A multistage sampling technique was used to recruit 1680 regular visitors to 24 primary health centres located in 12 local governments across six states for this cross-sectional validation study. This involved the selection of a state from each geopolitical zone by simple random sampling. Stratified random sampling technique was also used to select a predominant rural and urban local government area (LGA) from selected States on the basis of remoteness, population and provision of essential services. The process which was assisted by staff of the ministry of health in these States saw the selection of 12 LGAs. Two PHCs were selected from each of these LGAs using a list of all PHC facilities obtained from the Federal Ministry of Health (FMOH, Nigeria, 2012a). Four of the 24 selected PHC centres were later replaced by others closest to them as they were not functioning at the time of the survey. Eventually, the 70 patients allocated per facility were recruited through convenience sampling.

Quantitative field data were analysed using SPSS version 20 (SPSS, 2011) with statistical significance interpreted with $P<0.05$. Statistical techniques were used to determine the internal structure of the questionnaire (exploratory factor analysis); the internal consistency reliability (Cronbach's $\alpha$ ); the construct and criterion validities (findings of the Pearson's correlation coefficient and structural equation modelling); and the acceptability (entire questionnaire and item response pattern). These procedures are explained below.

Internal structure. Principal component extraction method with varimax rotation identified linear components within the scale and reduced items into possible underlying dimensions. The KaiserMeyer-Oilkin (KMO) normalisation and Bartlett's test of sphericity where indices that confirmed if the sample size was adequate for factor analysis. A re-analysis which included only items that had eigenvalues $\geqslant 1$, factor loading $\geqslant 0.50$ and a difference of 0.15 between factors was done (Streiner and Norman, 2008; Field, 2013).

Acceptability. The various indices for assessing acceptability (as defined and used in the earlier quantitative survey) were reported for final items in the questionnaire.

Reliability. Internal consistency which estimates the degree of relatedness of all items in the questionnaire was determined by the Cronbach's $\alpha$. Acceptable $\alpha$ should be $>0.7$ for the questionnaire and its domains (Streiner and Norman, 2008).

Validity. Demonstrating latent or hypothetical constructs can be problematic where there are no clear 'gold standards' or referents. A series of converging statistical tests used to demonstrate the 
construct validity of this multi-dimensional questionnaire as explained below:

- The convergent and discriminant validities of items and domains in this multi-dimensional questionnaire were demonstrated from their partial correlation coefficients (Campbell and Fiske, 1959; Streiner and Norman, 2008). We examined if items within the domains (set of items) in this multi-dimensional questionnaire measure same or different constructs (domains) and subsequently explored the relationships between these domains and the entire questionnaire. Items defining latent or hypothetical constructs are expected to correlate significantly more with a domain they are theoretically associated with, than with other domains in the scale. Convergent validity is supported if (a) Cronbach's $\alpha$ for each domain or entire questionnaire is $>0.7$, (b) there is moderate to high correlation between entire questionnaire and its domains $(>0.4)$, (c) there is moderate to high correlation between item and entire questionnaire $(>0.4)$, (d) the item-item correlation within domain is $>0.2$, (e) the Cronbach's $\alpha$ of a particular domain is substantially higher than its correlation coefficients with other domains.

- The Discriminant validity is similarly supported with the moderate correlation between domains. This indicates that they measure distinct aspects of the same constructs (Campbell and Fiske, 1959; Ware and Gandek, 1998; Streiner and Norman, 2008).

The construct was further demonstrated by the questionnaire's ability to discriminate scores between the group. Construct validity is supported, if in line with a priori hypothesis, female patients or those with better self-rated health status, are associated with significantly higher evaluation scores (Al-Mandhari et al., 2004; Baltaci et al., 2013). The relationship between evaluation scores and these explanatory variables were examined using structural equation modelling from regression analyses.

The correlation between the short-form (PES-SF) and full PES (PES before psychometric validation survey), patients' general satisfaction, willingness to return or recommend the centre to friends, was conducted to demonstrate the concurrent validity of PES-SF (Fitzpatric et al., 1998; Ramsay et al., 2000; Webster et al., 2011).

\section{Ethics and permission}

The ethics committee at the University of Manchester (ref no. 14280) granted approval for this study. Permissions were obtained from the local ministries or PHC boards in Rivers, Benue, Lagos, Adamawa, Bayelsa States and from participating local government councils in Anambra, Kaduna and the Federal Capital Territory. Eligible participants in all phases of the research were outpatients; aged $\geqslant 18$ years; attended selected health centres at least once in the preceding six months; and gave consent to participate. Patients participation in all phases of the research was voluntary, potential participants received detailed information on the research and assurance of confidentiality before giving signed consent. Each participant later received 250 naira (c. £1) in appreciation for the time they spent being involved in the research.

\section{Field assistants}

Eight field assistants were trained at the commencement of the research and these continued with the team through the various phases of the research. During the training, narrative accuracy checks using health workers with dual linguistic skills in specific locations were used in validating translated data by team's assistants who served as interpreters during the qualitative interviews and also assisted in the administration of questionnaires to less literary-skilled participants during the various quantitative studies.

\section{Results}

\section{Item generation}

Most of the 23 identified measures had limitations in their appropriateness for use in the Nigerian PHC setting. In all, 27 of the 47 qualitative interviews were conducted in the north, 25 were with female patients, and the English language was the medium of communication in 25 interviews. Most of the items (36 of the 39 items) in the draft questionnaire were generated from content analyses of interview transcripts. The remaining items-patient general satisfaction, the likelihood of return and recommending friends and family members to the centre, as well as patient sociodemographic variables were extracted from available studies. 


\section{Face and content validity}

In all, 25 out of the 39 items were rated relevant by all experts; a further 12 by five of the six experts while two were rated relevant by only four experts. The calculated i-CVI ranged from 0.67 to 1.00 while the s-CVI was 0.93 . The ICC for absolute agreement among experts of $0.93[F(5,190)=15.1, P<0.001]$ shows that the level of agreement among experts was too substantial to have been due to chance. Two items evaluating telephone access and staff punctuality with $\mathrm{i}-\mathrm{CVI} \leqslant 0.78$ were deleted. In the subsequent round, 12 items were considered not feasible for accurate assessments by patients leaving the questionnaire with 27 items under eight domains. The instruction permitted patients to omit items they consider not applicable to them as the do not know/doesn't apply response option was not accommodated.

Further revisions were made after the 'thinkaloud' sessions and these included the addition of timeframe to the first two items; reference made to particular staff consulted in the facility in item 14; making the style and clarity of the independent variables clearer.

\section{Quantitative pre-test}

Respondents in the first quantitative pilot survey were mostly female $(87.4 \%)$, married (91.9\%), had consultations with nurses $(54.8 \%)$ and did not pay for the services they received $(63.7 \%)$. The mean response rate was $95 \%$ while the item non-response rates were higher in the last three items that had 11-point response format (7.4, 15.8 and $6.7 \%$, respectively) as well as response to the question on age which was openended $(16.8 \%)$. The acceptability of items was comparable across population groups in this survey but there was a general aversion for endorsing lowest points on the multipoint response formats (mean $=2.0 \%$, range $0-14.4$ ) and a tendency for endorsing the highest point (mean = $48.7 \%$, range $32.2-71.1$ ). Mid options in the 11-point response format were also mostly redundant. Subsequent revisions which were tested in the subsequent experiments included the adoption of five-point response format for all items and creating age ranges.

The result of the research done to compare the performance of two commonly used response formats revealed that patients were $50 \%$ more likely
$(\mathrm{OR}=1.54, \quad 95 \%$ confidence interval $(\mathrm{CI})$ : $1.27-1.89, P<0.001)$ to respond to items with adjectival response format than Likert-type format. By contrast, mean item score was significantly higher in the Likert-type variant (SMD $=0.12$, 95\% CI: $0.08-0.17, P=0.02$ ). The decision to trade higher item score for validity from these evidence formed the basis for adopting the adjectival response format for PES.

The full version of PES had 27 items which were grouped into eight domains (facility, geographic access, organisation, financial access, staff, waiting time, consultation and benefits). In all, 25 items had five-point adjective response format while the remaining indicated duration in time spent coming to the centre and waiting in the centre before being attended to by the health providers. PES can be completed in a mean time of $12.7( \pm 5.5)$ min while patients' grading of the ease of completing the questionnaire on a $1-7$ scale was $5.5(\mathrm{SD}=1.4)$.

\section{Psychometric validation}

From Table 1, more of the 1649 respondents that returned the questionnaire were aged 20-29 years $(40 \%)$, female $(73 \%)$, married $(73 \%)$, perceived their health status as at least good (78\%).

\section{Dimensionality}

From Table 2, the principal component extraction method with varimax rotation and Kaiser's normalisation produced three domains (with five items each). These were codenamed facility, organisation and health care. The KMO of 0.88 and the Bartlett's test of sphericity $\left(\chi^{2}=7691.8\right.$, $\mathrm{df}=105, P<0.001)$ confirmed sample adequacy for factor analysis. Scree plot (Appendix 1) shows that this three-component solution explains $56.6 \%$ of the common variance of perceived quality of PHC in Nigeria.

\section{Acceptability}

Acceptability measures across population groups presented in Tables 3 and 4 show that a response rate of $98.2 \%$ ranged from 84 to $100 \%$ across facilities. There are minimal skewness and kurtosis observed in the distribution characteristics of item and domain scores. The charts of the score distributions of items in the domains and entire questionnaire show near Normal 
distribution (Appendix 2). The floor and ceiling effects of items in the questionnaire presented in Table 4 show a mean floor effect of $4.8 \%$ with a

Table 1 Respondents' characteristics in validation survey ( $n=1649)$

\begin{tabular}{|c|c|}
\hline Variables & Descriptive (\%) \\
\hline Age stratum (years) & $\begin{array}{l}<20(11.2), 20-29(40.6), 30-39(33.3), \\
40-60(12.3),>60(2.6)\end{array}$ \\
\hline Gender & Male - 27.3 \\
\hline Marital status & Currently single -28.3 \\
\hline Level of schooling & $\begin{array}{l}\text { No formal education (11.8), primary } \\
(19.1) \text {, secondary (42.8), post- } \\
\text { secondary (26.3) }\end{array}$ \\
\hline Working status & No paid employment - 51.2 \\
\hline Religion & $\begin{array}{l}\text { Christian (71.9), Moslem (27.2), } \\
\text { others }(0.8)\end{array}$ \\
\hline $\begin{array}{l}\text { Perceived health } \\
\text { status }\end{array}$ & $\begin{array}{l}\text { Poor (3.5), fair (18.6), good (41.0), } \\
\text { very good (26.5) and excellent (10.3) }\end{array}$ \\
\hline $\begin{array}{l}\text { Payment for health } \\
\text { care }\end{array}$ & $\begin{array}{c}\text { Free service (22.4), insurance (1.3), paid } \\
\text { by self }(51.1) \text {, paid by others }(25.2)\end{array}$ \\
\hline Region of country & North $(50.2)$ \\
\hline $\begin{array}{l}\text { Facility location - } \\
\text { State }\end{array}$ & $\begin{array}{l}\text { Lagos (16.6), Bayelsa (17.0), } \\
\text { Anambra (16.3), Adamawa (16.6), } \\
\text { Kaduna (16.7), Benue (16.8) }\end{array}$ \\
\hline $\begin{array}{l}\text { Professional } \\
\text { consulted at facility }\end{array}$ & $\begin{array}{l}\text { Doctor (19.9), Nurse (56.6), CHP } \\
(22.3)\end{array}$ \\
\hline Contact with centre & $<1$ year $(52.6)$ \\
\hline
\end{tabular}

$\mathrm{CHP}=$ Community Health Practitioner. range of $0.9-14.2 \%$. In addition, the mean ceiling effect was $13.0 \%$ with a range of $4.9-19.1 \%$. The chart of the floor and ceiling effects of the various items in the questionnaire are presented in Appendix 3.

\section{Reliability}

The Cronbach's $\alpha$ coefficient for the entire questionnaire was 0.87 and for the facility, organisation and health care domains were $0.81,0.79$ and 0.78 , respectively (Table 4 ).

\section{Validity}

Items correlated more significantly with their hypothesised domain (asterisked) than with other domains (Table 4). Convergent validity is supported by (a) the high internal consistencies of the domains and entire questionnaire; (b) moderate to high correlation between domains and total scores, item-domain (and domain-total) correlation $>0.4$; (d) item-total correlation of $>0.4$; (e) domain's reliability coefficient (Cronbach's $\alpha$ ) being substantially higher than their correlation with other domains. Similarly, discriminant validity was supported by (a) moderate correlation between domains indicating their measurement of distinct

Table 2 Item loading during exploratory factor analysis ${ }^{a}$

\begin{tabular}{llllr}
\hline Number & Item description & \multicolumn{2}{l}{ Component } & \\
\cline { 3 - 5 } & & 1 & 2 & 3 \\
\hline 1 & & 0.72 & 0.04 & 0.21 \\
2 & Adequacy of space in waiting area & $\mathbf{0 . 7 9}$ & 0.13 & 0.21 \\
3 & Seating arrangements & $\mathbf{0 . 7 0}$ & 0.25 & -0.04 \\
4 & Suitable temperature inside & $\mathbf{0 . 7 4}$ & 0.12 & 0.14 \\
5 & Attractiveness of centre & $\mathbf{0 . 6 9}$ & 0.07 & 0.32 \\
6 & Neatness of facility & 0.20 & 0.18 & $\mathbf{0 . 5 5}$ \\
7 & Ease of payment & 0.14 & 0.03 & $\mathbf{0 . 7 6}$ \\
8 & Convenience of opening times & 0.18 & 0.26 & $\mathbf{0 . 7 5}$ \\
9 & Staff receptiveness & 0.16 & 0.30 & $\mathbf{0 . 7 2}$ \\
10 & Staff perceived capability & 0.12 & 0.32 & $\mathbf{0 . 6 5}$ \\
11 & Relationship with staff & 0.17 & $\mathbf{0 . 6 5}$ & 0.06 \\
12 & Promptness in service delivery & 0.14 & $\mathbf{0 . 6 5}$ & 0.27 \\
13 & Safety of care & 0.19 & $\mathbf{0 . 7 0}$ & 0.20 \\
14 & Consultation time & 0.06 & $\mathbf{0 . 7 8}$ & 0.19 \\
15 & Health information & 0.02 & $\mathbf{0 . 7 0}$ & 0.24 \\
& Clear communication & & & \\
\hline
\end{tabular}

${ }^{a}$ Principal component analysis with varimax rotation and Kaiser normalisation after excluding items that did not meet recommended psychometric criteria on acceptability, factor loading, internal consistency and homogeneity. The Kaiser-Meyer-Oilkin measure for sampling adequacy was 0.88 and the Bartlett's test of sphericity $\left(\chi^{2}=7691.8, \mathrm{df}=105\right.$ and $P$-value $\left.<0.001\right)$. Bold item load $>0.5$ and the three subscales explained a total of $56.6 \%$ of the total variance of the construct. 
Table 3 Response pattern across population groups

\begin{tabular}{|c|c|c|c|c|}
\hline \multirow[t]{2}{*}{ Group variable } & \multicolumn{4}{|c|}{ Measures of acceptability across population groups } \\
\hline & $\begin{array}{l}\text { Response rate } \\
\text { [mean (range)] }^{\text {a }}\end{array}$ & $\begin{array}{l}\text { INRR in percentage } \\
\text { [mean (range)] }\end{array}$ & $\begin{array}{l}\text { Floor } \\
\text { [mean (range)] }\end{array}$ & $\begin{array}{l}\text { Ceiling } \\
\text { [mean (range)] }\end{array}$ \\
\hline \multicolumn{5}{|l|}{ Region } \\
\hline North & $98.5(95.7-100.0)$ & $1.2(0.6-1.9)$ & $4.9(1.0-15.8)$ & $9.4(4.9-14.9)$ \\
\hline South & $97.9(84.3-100.0)$ & $1.8(0.7-2.6)$ & $4.6(0.0-14.9)$ & $16.6(4.6-25.3)$ \\
\hline \multicolumn{5}{|l|}{ Location } \\
\hline Urban & $97.4(84.3-100.0)$ & $1.1(0.4-1.9)$ & $5.5(1.1-12.2)$ & $12.2(2.9-22.0)$ \\
\hline Rural & $98.9(95.7-100.0)$ & $1.9(1.0-2.9)$ & $4.0(0.5-16.2)$ & $13.8(6.9-19.1)$ \\
\hline \multicolumn{5}{|l|}{ State } \\
\hline Lagos & $97.5(94.3-100.0)$ & $5.1(2.0-7.3)$ & $10.9(1.5-39.5)$ & $20.3(5.6-30.7)$ \\
\hline Bayelsa & 100.0 & $0.8(0.0-1.8)$ & $0.6(0.0-3.2)$ & $14.6(3.6-39.6)$ \\
\hline Anambra & $96.1(84.3-100.0)$ & $5.2(4.1-6.1)$ & $2.8(0.0-18.2)$ & $15.1(4.5-27.3)$ \\
\hline Adamawa & $97.9(95.7-98.6)$ & $3.9(3.1-5.3)$ & $3.9(0.4-13.0)$ & $14.3(3.3-26.6)$ \\
\hline Kaduna & $98.6(97.1-100.0)$ & $2.2(1.4-3.4)$ & $4.3(0.0-20.9)$ & $6.4(0.7-16.8)$ \\
\hline Benue & $98.9(97.1-100.0)$ & $2.1(1.4-2.9)$ & $6.6(1.1-20.7)$ & $7.4(4.0-11.4)$ \\
\hline \multicolumn{5}{|l|}{ Gender } \\
\hline Male & - & $1.4(0.5-2.7)$ & $6.1(0.9-18.5)$ & $12.7(5.3-19.3)$ \\
\hline Female & - & $1.4(0.7-2.6)$ & $4.3(1.0-12.6)$ & $13.1(4.9-19.7)$ \\
\hline \multicolumn{5}{|l|}{ Age group } \\
\hline Young & - & $1.2(0.8-2.3)$ & $4.6(0.9-13.3)$ & $13.1(4.9-19.6)$ \\
\hline Middle & - & $1.5(0.0-4.0)$ & $6.0(0.5-18.5)$ & $12.5(3.5-19.7)$ \\
\hline Elderly & - & $1.2(0.0-2.3)$ & $5.5(0.0-19.0)$ & $11.2(0.0-20.9)$ \\
\hline
\end{tabular}

INRR = item non-response rate.

${ }^{\text {a }}$ Reported by health centre.

aspects of same constructs; (b) significantly higher correlation between items and their hypothesised domain than with other domains. The shortened version of the questionnaire resulted from the removal of nine items which did not attain 'a priori' criteria for factor loading and discriminant validity.

PES-SF questionnaire and domain scores could differentiate population groups on the basis of gender and self-rated health status. There was also moderate to large correlation with PES, patients' general satisfaction/likelihoods of returning/ recommending close friends and relatives to the health centre (Table 5). The detailed contents of PES and PES-SF are presented in Appendix 4, respectively.

\section{Discussion}

Article summarised the development and validation of the patient evaluation scale developed for use in the Nigerian PHC setting. The mixed method iterative development involving literature reviews, patient interviews, expert reviews, think-aloud sessions and waves of quantitative cross-sectional surveys with PHC patients resulted in the full form of the questionnaire. This full PES was trimmed following psychometric validation to provide three domains (with five items each) that had acceptable good Cronbach's $\alpha$ and showed adequate convergent and discriminant validity. This shortened version also showed significant positive correlation with the full PES and other single-item measures.

\section{Comparing findings}

Face and content validation ensured that questionnaire's items and instructions were clear, comprehensive and comprehensible to the patients and this could potentially help to reduce measurement errors (Nunnally et al., 1967). The process of content validation permitted the deletion of items that were conceptually irrelevant and this also helps to ensure the content adequacy of the questionnaire. From this initial process, items evaluating telephone access and staff punctuality were deleted. This is surprising as 
Table 4 Descriptive statistics and measurement properties of patient evaluation scale short form (PES-SF)

\begin{tabular}{|c|c|c|c|c|c|}
\hline \multirow[t]{2}{*}{ Properties } & \multirow[t]{2}{*}{ Description of variable } & \multicolumn{3}{|l|}{ Domains } & \multirow{2}{*}{$\begin{array}{l}\text { Entire } \\
\text { questionnaire }\end{array}$} \\
\hline & & Facility & Organisation & Health care & \\
\hline \multirow[t]{7}{*}{ Descriptive } & No of items & 5 & 5 & 5 & 15 \\
\hline & Mean & 49.81 & 60.89 & 56.92 & 55.69 \\
\hline & SD & 20.4 & 19.0 & 18.3 & 15.3 \\
\hline & Skewness & -0.04 & 0.04 & 0.06 & 0.06 \\
\hline & Kurtosis & -0.34 & -0.65 & -0.31 & -0.07 \\
\hline & \% Floor (mean, range) & $9.1(4.6-14.2)$ & $2.9(1.1-8.6)$ & $2.5(0.9-3.7)$ & $4.8(0.9-14.2)$ \\
\hline & $\%$ Ceiling (mean, range) & $9.6(4.9-19.0)$ & $17.2(14.1-19.1)$ & $12.1(10.4-13.6)$ & ) $13.0(4.9-19.1)$ \\
\hline \multirow{6}{*}{$\begin{array}{l}\text { Construct validity of } \\
\text { subscale and scale }^{a}\end{array}$} & Range of item loading & $0.51-0.63$ & $0.55-0.76$ & $0.65-0.78$ & $0.51-0.78$ \\
\hline & $\begin{array}{l}\text { Range of item-subscale } \\
\text { correlation }^{c}\end{array}$ & $0.53-0.69$ & $0.44-0.67$ & $0.46-0.67$ & $0.46-0.60$ \\
\hline & $\begin{array}{l}\text { Range of item-other subscale } \\
\text { correlation }^{d}\end{array}$ & $0.23-0.43$ & $0.31-0.47$ & $0.21-0.45$ & - \\
\hline & Range of item-total correlation ${ }^{\mathrm{e}}$ & $0.47-0.57$ & $0.47-0.61$ & $0.42-0.55$ & $0.42-0.61$ \\
\hline & Cronbach's $\alpha^{f}$ & 0.81 & 0.79 & 0.78 & 0.87 \\
\hline & $\alpha$, scale deleted & 0.70 & 0.52 & 0.63 & - \\
\hline \multirow{15}{*}{$\begin{array}{l}\text { Item correlation with } \\
\text { various domains } \\
\text { and entire scale }\end{array}$} & $\begin{array}{l}\text { Adequacy of waiting area } \\
\text { space }(0.54)\end{array}$ & $0.59^{\mathrm{h}, *}$ & 0.34 & 0.23 & 0.47 \\
\hline & Seating provisions $(0.63)$ & $0.69 *$ & 0.38 & 0.31 & 0.57 \\
\hline & Internal temperature $(0.51)$ & $0.53^{*}$ & 0.24 & 0.29 & 0.44 \\
\hline & $\begin{array}{l}\text { Attractiveness of centre } \\
(0.56)\end{array}$ & $0.62 *$ & 0.30 & 0.26 & 0.49 \\
\hline & Cleanliness of centre $(0.62)$ & $0.59 *$ & 0.43 & 0.29 & 0.55 \\
\hline & Ease of payment (0.55) & 0.32 & $0.44 *$ & 0.36 & 0.47 \\
\hline & $\begin{array}{l}\text { Convenience of operating } \\
\text { times }(0.76)\end{array}$ & 0.32 & $0.55^{*}$ & 0.31 & 0.47 \\
\hline & $\begin{array}{l}\text { Receptiveness by staff } \\
(0.75)\end{array}$ & 0.37 & $0.67^{*}$ & 0.44 & 0.61 \\
\hline & $\begin{array}{l}\text { Staff perceived capability } \\
(0.72)\end{array}$ & 0.35 & $0.64 *$ & 0.46 & 0.61 \\
\hline & $\begin{array}{l}\text { Relationship with staff } \\
(0.65)\end{array}$ & 0.31 & $0.56^{*}$ & 0.47 & 0.55 \\
\hline & $\begin{array}{l}\text { Promptness in receiving } \\
\text { care }(0.65)\end{array}$ & 0.25 & 0.31 & $0.46^{*}$ & 0.42 \\
\hline & View on safety of care $(0.65)$ & 0.29 & 0.45 & $0.55^{*}$ & 0.53 \\
\hline & $\begin{array}{l}\text { View on consultation time } \\
(0.70)\end{array}$ & 0.31 & 0.42 & $0.59 *$ & 0.55 \\
\hline & Health information (0.78) & 0.24 & 0.40 & $0.64 *$ & 0.51 \\
\hline & Clarity of information (0.70) & 0.21 & 0.42 & $0.55^{*}$ & 0.47 \\
\hline
\end{tabular}

a Domain-total correlation coefficient (0.46-0.60), inter-domain correlation coefficient (0.36-0.54).

${ }^{b}$ Range of item loading, only items with eigenvalue $>1$ and factor loading value (FLV) $>0.5$ were included in the final questionnaire.

${ }^{c}$ Range of corrected item and hypothesised domain correlation with relevant items removed from scale for correlation.

${ }^{d}$ Range of corrected correlation between item and other domains with relevant items removed from scale for correlation.

e Range of correlation between individual items in the domains and the total PES-SF questionnaire with relevant items removed from questionnaire for correlation.

${ }^{f}$ Cronbach's $\alpha$ is the overall reliability of items in their hypothesised scales.

${ }^{g}$ Values in parenthesis are the FLV of individual item in the questionnaire.

${ }^{\mathrm{h}}$ Values asterisked are the various item correlations with their hypothesised domains.

telephone access would have been accorded high relevance in most other settings. For example, two of the 23 items in the EUROPEP instrument, developed for patient evaluation of PHC in European setting are meant to evaluate telephone access (Grol et al., 2000). However, despite mobile

Primary Health Care Research \& Development 2017; 18: 161-182 
telephone revolution in Nigeria, fixed business lines still remain a rarity, expensive and fraught with inefficiency (Adeoti and Adeoti, 2008). Furthermore, currently organisation of PHC has no provision for receptionists to manage telephone calls to health centres.

During the initial quantitative survey, there were more missing items, redundancies in the midpoints of the response scale and ceiling effects in relation to the use of 11-point responses response format when compared with the fivepoint response format. This finding which supports earlier reports of higher variance and reliability along with reduced bias with the use of five-point response format (Streiner and Norman, 2008) offered another opportunity to uniformly adopt the five-point response format for PES.

Similarly, there was a reduction from 16.8 to $1.3 \%$ in non-response when age was changed from open-ended to closed response format. This situation which either demonstrates patients' unwillingness to divulge information on actual age or poor awareness on this by a large proportion of respondents led to the creation of age strata in the PES questionnaire.

In comparing two different response formats, there was about a $50 \%$ higher chance of item responses with the adjectival response format. The adjectival response format is less commonly used in questionnaires for patient evaluation of $\mathrm{PHC}$ (Grol et al., 2000; Harmsen et al., 2005) than the Likert-type response (Baker, 1990; Laerum et al., 2004; Bjertnaes et al., 2011; Webster et al., 2011; Yang et al., 2013). There is no report of any previous comparison of the performance of these response formats along criteria used in this study. Nonetheless, our finding coupled with the fact that PES is more of an evaluative than a discriminative measure, justified the use of adjectival response format.

The validity of patient survey is enhanced by the low level of item non-response and high response rates to the questionnaire (Streiner and Norman, 2008). Both PES and PES-SF had mean item nonresponse rate much lower than target limit of $10 \%$ recommended for item deletion and questionnaire response rate from the various quantitative surveys were also very high (Streiner and Norman, 2008). High response rates are also commonly reported with patients' surveys in PHC across Sub-Saharan Africa (Baltussen et al., 2002; Oladapo et al., 2008; Oladapo and Osiberu, 2009;
Udonwa et al., 2010; Ogaji and Etokidem, 2012) when compared with other settings (Grogan et al., 2000; Ramsay et al., 2000; Campbell et al., 2007; 2009; Bjertnaes et al., 2011; Bova et al., 2012; Yang et al., 2013). While the impact of financial incentives or mode of questionnaire administration on the response rate remains unclear, high response to a questionnaire is indicative of the extent respondents are willing and able to complete a survey. The high level of acceptability observed in the general population was also demonstrated across population groups in the series of quantitative surveys. This in part shows that the questionnaire is suitable for use among different groups and constituents in Nigeria's diverse population.

Questionnaires' dimensions, reliability and validity are often derived from psychometric analyses (Rosnow and Rosenthal, 1996; Safran et al., 1998; Campbell et al., 2007; Streiner and Norman, 2008; Webster et al., 2011). The validity of PES was assured by the process of content validation using experts and patients; factor analysis and determination of domains (set of items); high internal consistency of scale/domains; the result of the convergent/discriminant as well as the criterion-related validity testing.

We reported details of the measurement properties of this questionnaire following the validation study. Previous measures have reported indices such as internal consistency (Wolf et al., 1978; Baker, 1991; Haddad et al., 1998; Safran et al., 1998; Grogan et al., 2000; Ramsay et al., 2000; Meakin and Weinman, 2002; Laerum et al., 2004; Mead et al., 2008; Lee et al., 2009; Bjertnaes et al., 2011; Halcomb et al., 2011; Webster et al., 2011; Bova et al., 2012; Vukovic et al., 2012; Roland et al., 2013; Yang et al., 2013), questionnaire's response rate (Baker, 1991; Safran et al., 1998; Grogan et al., 2000; Ramsay et al., 2000; Meakin and Weinman, 2002; Greco et al., 2003; Campbell et al., 2007; Bjertnaes et al., 2011; Bova et al., 2012; Yang et al., 2013) and divergent properties (Baker, 1991; Grogan et al., 2000; Ramsay et al., 2000; Harmsen et al., 2005; Lee et al., 2009; Halcomb et al., 2011). Less frequently reported measures are floor and ceiling effects (Safran et al., 1998; Campbell et al., 2007; Bjertnaes et al., 2011), inter-item correlation (Haddad et al., 1998; Meakin and Weinman, 2002; Campbell et al., 2007), item-total correlation (Haddad et al., 1998; Safran et al., 1998; 
Table 5 Patient evaluation scale (PES) short form scores compared between patients' groups and other scales

\begin{tabular}{|c|c|c|c|c|}
\hline \multirow[t]{3}{*}{ Predictor variable } & \multicolumn{4}{|l|}{ Estimate $(95 \% \mathrm{Cl})$} \\
\hline & \multicolumn{3}{|l|}{ Subscales } & \multirow[t]{2}{*}{ Entire scale } \\
\hline & Facility & Organisation & Health care & \\
\hline Gender $^{\mathrm{a}}$ & $4.91(2.72,7.10)^{\mathrm{b}, * * *}$ & $2.54(0.49,4.59)^{*}$ & $2.25(-2.21,1.72)$ & $2.40(0.76,4.04)^{* * *}$ \\
\hline Self-rated health status ${ }^{c}$ & $5.39(3.06,7.73)^{b, * * *}$ & $8.82(6.67,10.97)^{* * *}$ & $11.68(9.66,13.70)^{* * *}$ & $8.63(6.92,10.34)^{* * *}$ \\
\hline Satisfaction & $0.31(0.29,0.36)^{d_{1 * * *}}$ & $0.49(0.45,0.53)^{* * *}$ & $0.43(0.38,0.48)^{* * *}$ & $0.51(0.47,0.55)^{* * *}$ \\
\hline Return to centre & $0.29(0.26,0.3)^{\mathrm{d}, * * *}$ & $0.47(0.42,0.51)^{* * *}$ & $0.41(0.35,0.46)^{* * *}$ & $0.48(0.44,0.52)^{* * *}$ \\
\hline Recommend others & $0.37(0.32,0.42)^{d, * * *}$ & $0.52(0.48,0.56)^{* * *}$ & $0.44(0.39,0.49)^{* * *}$ & $0.55(0.51,0.59)^{* * *}$ \\
\hline Original PES & $0.74(0.72,0.77)^{d_{* * *}}$ & $0.80(0.78,0.81)^{* * *}$ & $0.76(0.73,0.78)^{* * *}$ & $0.96(0.96,0.97)^{* * *}$ \\
\hline
\end{tabular}

${ }^{a}$ Referent group in this univariate linear regression were males.

${ }^{b} B$ coefficient from univariate linear regression analysis.

${ }^{\mathrm{c}}$ Referent group were those with poor/fair self-rated health status.

${ }^{\mathrm{d}}$ Pearson's correlation coefficient $[95 \%$ confidence interval $(\mathrm{Cl})], P$-value: ${ }^{*}<0.05,{ }^{*} *{ }^{*}<0.001$.

Campbell et al., 2007), inter-scale correlation (Wolf et al., 1978; Safran et al., 1998; Lee et al., 2009), questionnaire's correlation with general satisfaction (Haddad et al., 1998; Ramsay et al., 2000; Webster et al., 2011), items' response rate (Bjertnaes et al., 2011; Yang et al., 2013), completion time (Safran et al., 1998), inter-rater reliability (Harmsen et al., 2005) and questionnaire's correlation with existing measure (Meakin and Weinman, 2002).

The 18 and 27-item versions of PES are easy to administer and will be useful for evaluating the structure, process and outcome quality dimensions of PHC in the Nigerian setting. We anticipate that practitioners and researchers would use these tools to identify strengths and weaknesses along aspects of $\mathrm{PHC}$ and to initiate patient-focussed quality improvement. The PES-SF scores correlate highly with those of the full PES and using the PES-SF may increase respondents' willingness and ease of participation with attendant reduction in administrator's stress in collecting and processing of data.

\section{Strengths and limitations}

The study strengths are underpinned by the empirical approaches used to generate items, the iterative design, consistent good measurement performance of PES from the series of crosssectional surveys, multi-centre testing across Nigeria, converging statistical proof of construct validity, and the involvement of PHC patients in all phases of development.
There are limitations from the various research methods applied in this study. For example, the opinions of subject experts and patients involved in various phases of PES development could vary from others in the general population. Although we found no report of the sociodemographic characteristics of PHC users in Nigeria, the study population varied markedly from the general Nigerian population. Another threat to external validity is the unavoidable use of non-probability sampling techniques in the final recruitment of subjects. The questionnaire is in English and some were administered by bilingual research assistants to patients who are not fluent in English. Despite the training and validation of interpreted data from these assistants, the use of interpreters in multiple response questionnaire surveys can still be problematic. Unfortunately, the responses from the self-administered and intervieweradministered questionnaires were not compared to ascertain if there are bias arising from the use of interpreters in multiple response questionnaires like the PES. A common observation with the PES is that though the wording of some items appear unconventional to international subjects, they are familiar to the Nigerian population.

The inclusion of empirically generated items in a questionnaire could enhance the suitability of both PES and PES-SF for patient-focussed quality improvement. However, PES may also be suitable for measuring some objectives of universal health coverage (equity, quality and financial protection) and also assessing some defining characteristics 
of PHC such as accessibility (geographic, financial, organisational); comprehensiveness, preventive focus, and effectiveness.

\section{Conclusion}

These multi-scale questionnaires were developed through a multi-phase process that involved primary care patients. PES fields a battery of items that covers important aspects of patients' experiences of PHC, has good measurement properties and consistently high acceptability across different population groups from the serial quantitative surveys. The shortened form is quite reliable and showed adequate convergent and discriminant validity. The PES and PES-SF may be useful in practice and research aimed at patient evaluation, comparing performance, understanding trends and testing patientfocussed improvements in PHC in Nigeria.

Future research will include investigating the sociodemographic characteristics of local users of PHC, translation of PES into major Nigerian languages and subsequent validation of these versions and further validation of PES against external quality criteria.

\section{Acknowledgements}

The authors are grateful to all the patients who took part in this study and PHC staff for all their support during data collection in all the phases of this research. We appreciate the cooperation of the National Primary Health Care Development Agency and the various ministries of health/primary health care boards in the states study was conducted. The authors would like to thank Steve Abah, Abisoye Oyeyemi, Wisdom Sawyer, Omosivie Maduka, Margaret Mezie-Okoye and Queen Eke, Andrew Abue, Uchenna Ugwoke, Lawrence Izang, Chimdi Nworgu, John Owoicho and Daniel Iyah who provided various assistance during this research work.

Authors' contributions: All authors were involved in conceptualising and planning of the study. Data collection was done by a team headed by D.S.O. D.S.O. also drafted the manuscript which was critically reviewed by others. All authors contributed to the interpretation of the results and also read and approved the final manuscript.

Primary Health Care Research \& Development 2017; 18: 161-182

\section{Financial Support}

This work was supported by a grant from the Niger Delta Development Commission (NDDC/ DEHSS/2013PGFS/RV/5).

\section{References}

Adeoti, J.O. and Adeoti, A.I. 2008: Easing the burden of fixed telephone lines on small-scale entrepreneurs in Nigeria: GSM lines to the rescue. Telematics and Informatics 25, $1-18$.

Al-Mandhari, A.S., Hassan, A.A. and Haran, D. 2004: Association between perceived health status and satisfaction with quality of care: evidence from users of primary health care in Oman. Family Practice 21, 519-27.

Baker, R. 1990: Development of a questionnaire to assess patients' satisfaction with consultations in general practice. The British Journal of General Practice 40, 487-90.

Baker, R. 1991: The reliability and criterion validity of a measure of patients' satisfaction with their general practice. Family Practice 8, 171-77.

Baltaci, D., Eroz, R., Ankarali, H., Erdem, O., Celer, A. and Korkut, Y. 2013: Association between patients' sociodemographic characteristics and their satisfaction with primary health care services in Turkey. Kuwait Medical Journal 45, 291-99.

Baltussen, R., Ye, Y., Haddad, S. and Sauerborn, R.S. 2002: Perceived quality of care of primary health care services in Burkina Faso. Health Policy and Planning 17, 42-48.

Bjertnaes, O.A., Lyngstad, I., Malterud, K. and Garratt, A. 2011: The Norwegian EUROPEP questionnaire for patient evaluation of general practice: data quality, reliability and construct validity. Family Practice 28, 342-49.

Bova, C., Route, P.S., Fennie, K., Ettinger, W., Manchester, G.W. and Weinstein, B. 2012: Measuring patient-provider trust in a primary care population: refinement of the health care relationship trust scale. Research in Nursing \& Health 35, 397-408.

Bowling, A. 2014: Research methods in health: investigating health and health services. Berkshire, England: McGraw-Hill Education (UK).

Campbell, D.T. and Fiske, D.W. 1959: Convergent and discriminant validation by the multitraitmultimethod matrix. Psychological Bulletin 56, 81-105.

Campbell, J., Smith, P., Nissen, S., Bower, P., Elliott, M. and Roland, M. 2009: The GP patient survey for use in primary care in the national health service in the UK - development and psychometric characteristics. BMC Family Practice $10,57$.

Campbell, J.L., Dickens, A., Richards, S.H., Pound, P., Greco, M. and Bower, P. 2007: Capturing users' experience of UK out-of-hours primary medical care: piloting and psychometric properties of the out-of-hours patient questionnaire. Quality \& Safety in Health Care 16, 462-68. 
Comrey, A.L. and Lee, H.B. 2013: A first course in factor analysis. East Sussex, UK: Psychology Press.

Crawford, M.J., Rutter, D., Manley, C., Weaver, T., Bhui, K., Fulop, N. and Tyrer, P. 2002: Systematic review of involving patients in the planning and development of health care. BMJ 325, 1263.

Field, A. 2013: Discovering statistics using IBM SPSS statistics. $4^{\text {th }}$ Edition, London, UK: Sage.

Fitzpatric, R., Davey, C., Buxton, M. and Jones, D. 1998: Evaluating patient based outcome measures for use in clinical trial. Health Technology Assessment 2, 1-74.

FMOH, Nigeria. 2005: The revised national health policy. Abuja: FMOH, Nigeria.

FMOH, Nigeria 2010: The national strategic health development plan (NSHDP) 2010-2015. Abuja, Nigeria: FMOH, Nigeria.

FMOH, Nigeria 2012a: Inventory of health facilities in Nigeria. Abuja, Nigeria: FMOH, Nigeria.

FMOH, Nigeria 2012b: National guidelines for the development of primary health care system in Nigeria, fourth edition. Abuja: NPHCDA.

Grant, J.S. and Davis, L.L. 1997: Selection and use of content experts for instrument development. Research in Nursing \& Health 20, 269-74.

Greco, M., Powell, R. and Sweeney, K. 2003: The improving practice questionnaire (IPQ): a practical tool for general practices seeking patient views. Education for Primary Care $14,440-48$.

Grogan, S., Conner, M., Norman, P., Willits, D. and Porter, I. 2000: Validation of a questionnaire measuring patient satisfaction with general practitioner services. Quality in Health Care 9, 210-15.

Grol, R.P.T.M., Wensing, M.J.P. and Olesem, F. 2000: Patients evaluate generalfamily practice: the EUROPEP instrument. Task Force on Patient Evaluations of General Practice Care. Nijmegen: World Organisation of Family Doctors (WONCA)/European Association for Quality in Family Practice.

Haddad, S., Fournier, P. and Potvin, L. 1998: Measuring lay people's perceptions of the quality of primary health care services in developing countries. Validation of a 20item scale. International Journal for Quality in Health Care 10, 93-104.

Halcomb, E.J., Caldwell, B., Salamonson, Y. and Davidson, P.M. 2011: Development and psychometric validation of the general practice nurse satisfaction scale. Journal of Nursing Scholarship 43, 318-27.

Harmsen, J.A.M., Bernsen, R.M.D., Meeuwesen, L., Pinto, D. and Bruijnzeels, M.A. 2005: Assessment of mutual understanding of physician patient encounters: development and validation of a mutual understanding scale (MUS) in a multicultural general practice setting. Patient Education \& Counseling 59, 171-81.

Hernan, A.L., Giles, S.J., O’Hara, J.K., Fuller, J., Johnson, J.K. and Dunbar, J.A. 2015: Developing a primary care patient measure of safety (PC PMOS): a modified Delphi process and face validity testing. BMJ Quality \& Safety, 1-8.
Hinkin, T.R. 1998: A brief tutorial on the development of measures for use in survey questionnaires. Organizational Research Methods 1, 104-21.

Laerum, E., Steine, S. and Finset, A. 2004: The patient perspective survey (PPS): a new tool to improve consultation outcome and patient involvement in general practice patients with complex health problems. Psychometric testing and development of a final version. Patient Education \& Counseling 52, 201-7.

Lagomarsino, G., Garabrant, A., Adyas, A., Muga, R. and Otoo, N. 2012: Moving towards universal health coverage: health insurance reforms in nine developing countries in Africa and Asia. The Lancet 380, 933-43.

Lee, J.H., Choi, Y.J., Sung, N.J., Kim, S.Y., Chung, S.H., Kim, J., Jeon, T.H. and Park, H.K 2009: Development of the Korean primary care assessment tool - measuring user experience: tests of data quality and measurement performance. International Journal for Quality in Health Care 21, 103-11.

Lynn, M.R. 1986: Determination and quantification of content validity. Nursing Research 35, 382-86.

Mead, N., Bower, P. and Roland, M. 2008: The general practice assessment questionnaire (GPAQ) - development and psychometric characteristics. BMC Family Practice 9, 11.

Meakin, R. and Weinman, J. 2002: The 'medical interview satisfaction scale' (MISS-21) adapted for British general practice. Family Practice 19, 257-63.

National Planning Commission/ICF International 2014: Nigeria. Demographic and health survey 2013. Abuja, Nigeria: National Planning Commission/ICF International.

National Population Commission 2006: National census report. Abuja, Nigeria: National Population Commission.

Nunnally, J.C., Bernstein, I.H. and Berge, J.M.T. 1967. Psychometric theory. New York: McGraw-Hill.

Ogaji, D. and Etokidem, A. 2012: Setting agenda for quality improvement in a public hospital in Nigeria using the consumers' judgement. IOSR Journal of Business and Management 1, 1-6.

Ogaji, D., Giles, S., Daker-White, G. and Bower, P. 2015: Systematic review of patients' views on the quality of primary health care in Sub-Saharan Africa. SAGE Open Medicine 3, p.2050312115608338.

Oladapo, O.T., Iyaniwura, C.A. and Sule-Odu, A.O. 2008: Quality of antenatal services at the primary care level in southwest Nigeria. African Journal of Reproductive Health 12, 71-92.

Oladapo, O.T. and Osiberu, M.O. 2009: Do sociodemographic characteristics of pregnant women determine their perception of antenatal care quality? Maternal and Child Health Journal 13, 505-11.

Polit, D.F. and Beck, C.T. 2006: The content validity index: are you sure you know what's being reported? Critique and recommendations. Research in Nursing \& Health 29, 489-97.

Ramsay, J., Campbell, J.L., Schroter, S., Green, J. and Roland, M. 2000: The general practice assessment survey (GPAS): tests of data quality and measurement properties. Family Practice 17, 372-79.

Roland, M., Roberts, M., Rhenius, V. and Campbell, J. 2013: GPAQ-R: development and psychometric properties of 
a version of the general practice assessment questionnaire for use for revalidation by general practitioners in the UK. BMC Family Practice 14, 160.

Rosnow, R.L. and Rosenthal, R. 1996: Beginning behavioral research: a conceptual primer. New Jersey, USA: PrenticeHall, Inc.

Safran, D.G., Kosinski, M., Tarlov, A.R., Rogers, W.H., Taira, D.A., Lieberman, N. and Ware, J.E. 1998: The primary care assessment survey: tests of data quality and measurement performance. Medical Care 36, 728-39.

SPSS Inc 2011: IBM SPSS statistics base 20. Chicago, IL: SPSS Inc.

Starfield, B. 1998: Primary care: balancing health needs, services, and technology. Oxford, UK: Oxford University Press.

Starfield, B., Shi, L. and Macinko, J. 2005: Contribution of primary care to health systems and health. Milbank Quarterly 83, 457-502.

Streiner, D.L. and Norman, G.R. 2008: Health measurement scales: a practical guide to their development and use. Oxford, UK: Oxford University Press.

Udonwa, N., Gyuse, A., Etokidem, A. and Ogaji, D. 2010: Client views, perception and satisfaction with immunisation services at primary health care facilities in Calabar, South-South Nigeria. Asian Pacific Journal of Tropical Medicine 3, 298-98.

Van Lerberghe, W. 2008: The world health report 2008: primary health care: now more than ever. Geneva, Switzerland: World Health Organization.

Vukovic, M., Gvozdenovic, B.S., Gajic, T., Gajic, B.S., Jakovljevic, M. and Mccormick, B.P. 2012: Validation of a patient satisfaction questionnaire in primary health care. Public Health 126, 710-18.
Ware, J.E. and Gandek, B. 1998: Methods for testing data quality, scaling assumptions, and reliability: the IQOLA Project approach. Journal of Clinical Epidemiology 51, 945-52.

Webster, T.R., Mantopoulos, J., Jackson, E., Cole-Lewis, H., Kidane, L., Kebede, S., Abebe, Y., Lawson, R. and Bradley, E.H. 2011: A brief questionnaire for assessing patient healthcare experiences in low-income settings. International Journal for Quality in Health Care 23, 258-68.

Wensing, M. and Elwyn, G. 2002: Research on patients' views in the evaluation and improvement of quality of care. Quality \& Safety in Health Care 11, 153-57.

Wolf, M.H., Putnam, S.M., James, S.A. and Stiles, W.B. 1978: The medical interview satisfaction scale: development of a scale to measure patient perceptions of physician behavior. Journal of Behavioral Medicine 1, 391-401.

World Health Organization 1978: Declaration of Alma Ata: report of the International Conference on Primary Health Care. Alma-Ata, USSR: World Health Organization.

World Health Organization 2006: Quality of care: a process for making strategic choices in health systems. Geneva, Switzerland: World Health Organization.

World Health Organization 2012: Health statistics and health information systems. Geneva, Switzerland: World Health Organization.

Yaghmale, F. 2003: Content validity and its estimation. Journal of Medical Education 3, 25-27.

Yang, H., Shi, L., Lebrun, L.A., Zhou, X., Liu, J. and Wang, H. 2013: Development of the Chinese primary care assessment tool: data quality and measurement properties. International Journal for Quality in Health Care 25, 92-105.

\section{Appendix 1}

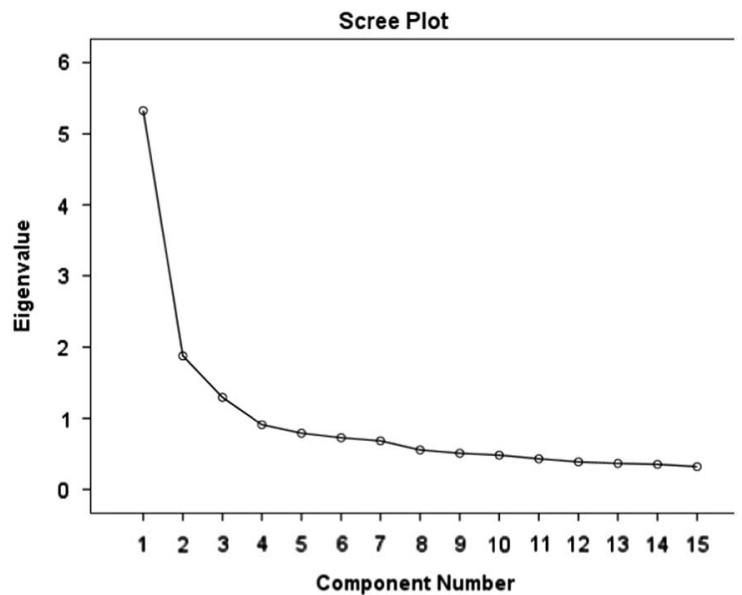

Figure A1 Total variance explained by three factors on Scree plot.

Primary Health Care Research \& Development 2017; 18: 161-182 


\section{Appendix 2}
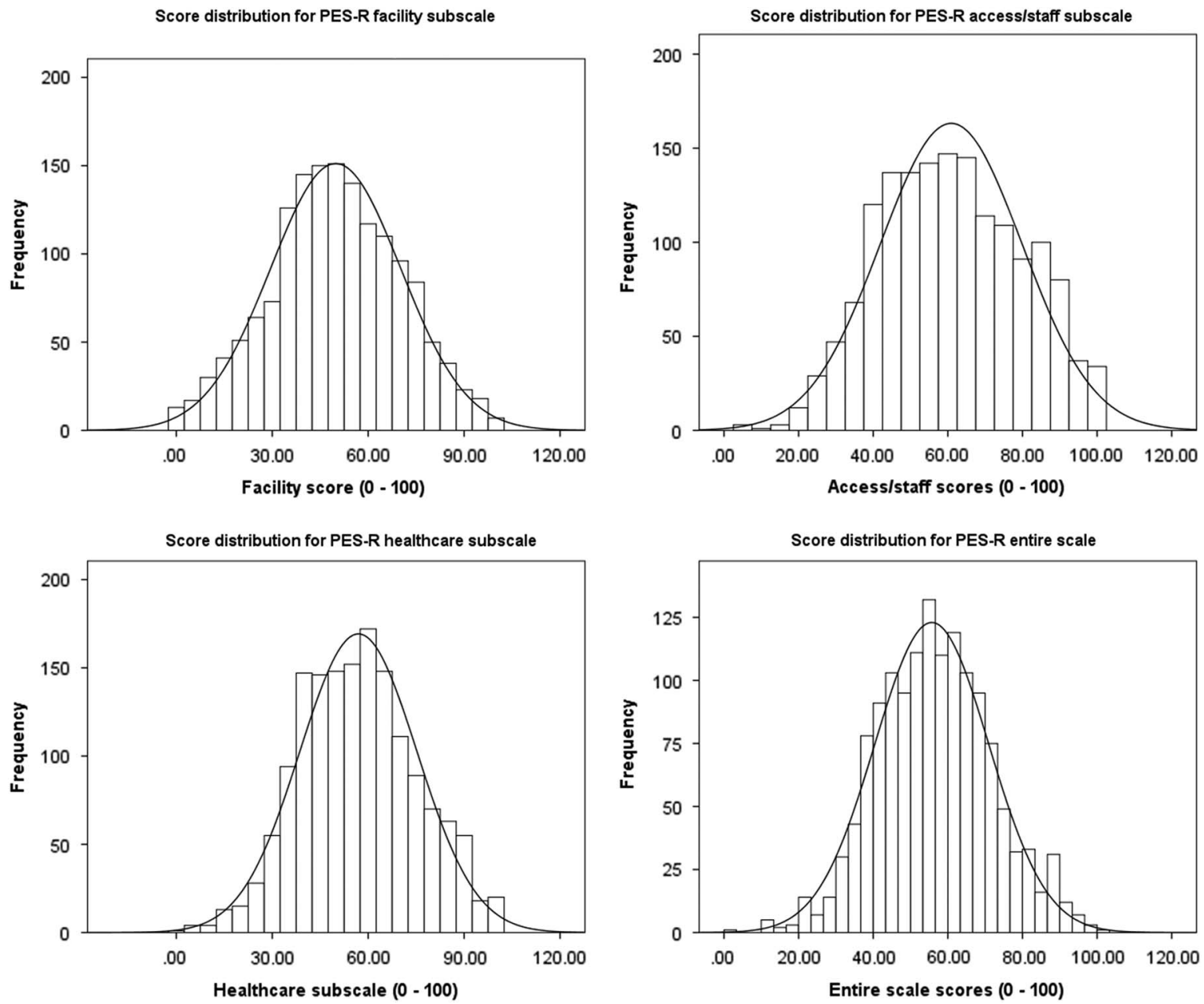

Figure A2 Score distribution for the domains and entire patient evaluation scale (PES) short form scale 


\section{Appendix 3}

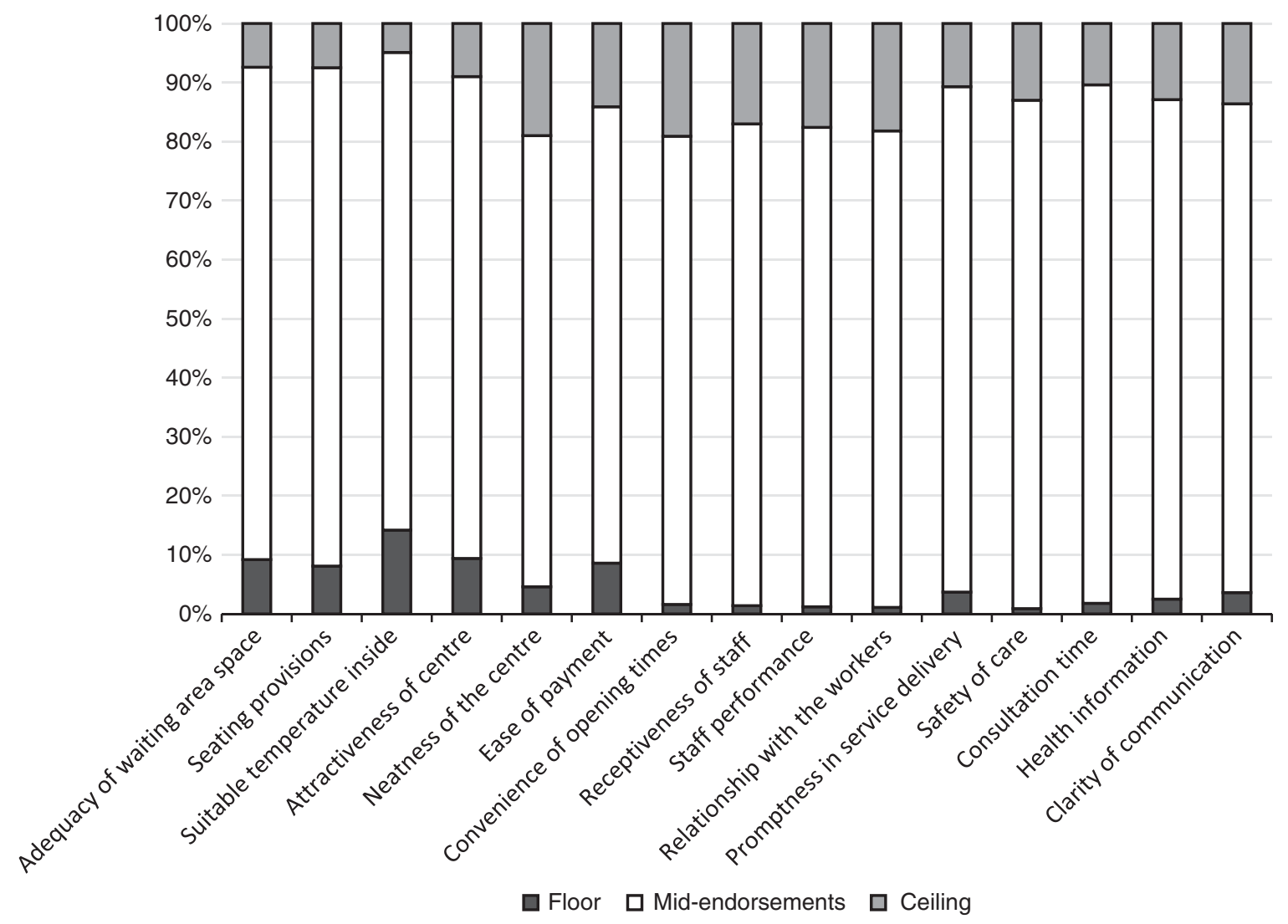

Figure A3 Floor and ceiling effects in patient evaluation scale short form 


\section{Appendix 4}

\section{THE PATIENTS' EVALUATION SCALE (PES) FOR PRIMARY HEALTH CARE IN NIGERIA}

\section{Please read before filling in this questionnaire}

Dear Client,

Thanks for accepting to participate in this survey.

This is a survey about you and your experience of primary health care. It is meant for only those who had used this health centre at least once previously in the last 12 months.

Please provide honest information about previous experience of the health centre and your visit today. Every question requires only one answer and you are required to leave out all questions you're either not sure about or are not applicable to you.

You do not need to think too long about your answers as your first answer will usually be your best. Also you are to fill this questionnaire only after you have finished what you came here to do.

You answer each question by marking $\boldsymbol{X}$ in the box that best describe your opinion and then after provide some information about yourself. If you have difficulty reading or require assistance when completing this questionnaire, a member of the research team is available to help you.

The information you give is confidential and would not be shared with anyone else including your health care provider, beside, no personal identifiable information will be collected from you. If you have any problem and wish to speak to the principal researcher, you can do so with the contact details below this instruction sheet.

Remember! You retain the right to withdraw your participation at any time.

Thank you for taking the time to complete this questionnaire.

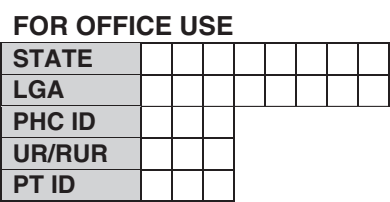

\section{A survey about your experience with your health centre}

Please initial the box if you

agree with the statement

1. I confirm that I have read and understand the information sheet for the above survey. I have had the opportunity to consider the information, ask questions and have had these questions answered satisfactorily

2. I understand that my participation is voluntary and that I am free to withdraw at any time, without giving any reason without my medical care and legal rights being affected in any way

3. I understand that data collected during the study, may be looked at by other individuals involved in this survey or related authorities, where it is relevant to my taking part in this research. I give permission for these individuals to have access to my records.

4. I agree to take part in the above study

Name of Participant

Researcher
Date

Date
Sgnature

Signature

Please complete both copies of this form and keep one for vour own records 


\section{About yourself}

$1 \quad$ How old are you?

$\square$ Less than 20 years

$\square 20-29$ years

$\square 30-39$ years

$\square$ 40 - 60 years

$\square$ More than 60 years

$2 \quad$ Are you male or female?

$$
\square \text { Male }
$$

$\square$ Female

$3 \quad$ What is your marital status?
$\square$ Not married
$\square$ Married
$\square$ Widowed/Divorced

4

What level of schooling did you complete?

$\square$ None

$\square$ Primary

$\square$ Secondary

$\square$ Intermediate (OND, HND, NCE)

$\square$ First degree (BSc, BA)

$\square$ Higher degree (PG Diploma, Master, PhD

$5 \quad$ What work do you do?

$\square$ I am not working

$\square$ I am a homemaker (Housewife)

$\square$ I am working for myself (Self-employed)

$\square$ I am working for the Government -

Federal, State or Local Government

$\square$ I am working for a private company

$\square$ I am a student

$\square$ Others (Please specify)

6 Which of the following best describes your religion?

$\square$ Christianity (includingatholics and protestants)

$\square$ Islam

$\square$ African traditional religion

$\square$ Atheist/non-religious

$\square$ Others (Please specify)

$\square$ I do not want to disclose my religion
$7 \quad$ Who attended to you today?

$\square$ A doctor

$\square$ A nurse

A community health worker

$\square$ Others (Please specify)

8 How would you rate your current state of health?
$\square$ Poor
$\square$ Fair
$\square$ Good
$\square$ Very good
$\square$ Excellent

9 How long have you been visiting this health centre?

$\square$ Less than 1 month

$\square 1$ month to less than 3 months

$\square 3$ months to less than 1 year

$\square 1$ year to less than 3 years

$\square$ More than 3 years

10 How did you pay for the care you received here today?

$\square$ It was free (No payment was made)

$\square$ I have an insurance or pre-paid scheme

$\square$ I paid with my own money

$\square$ I paid with money from other sources (e.g.

spouse, family, friends' etc.) 


\section{Core items in Short form of Patient Evaluation Scale (PES-SF)}

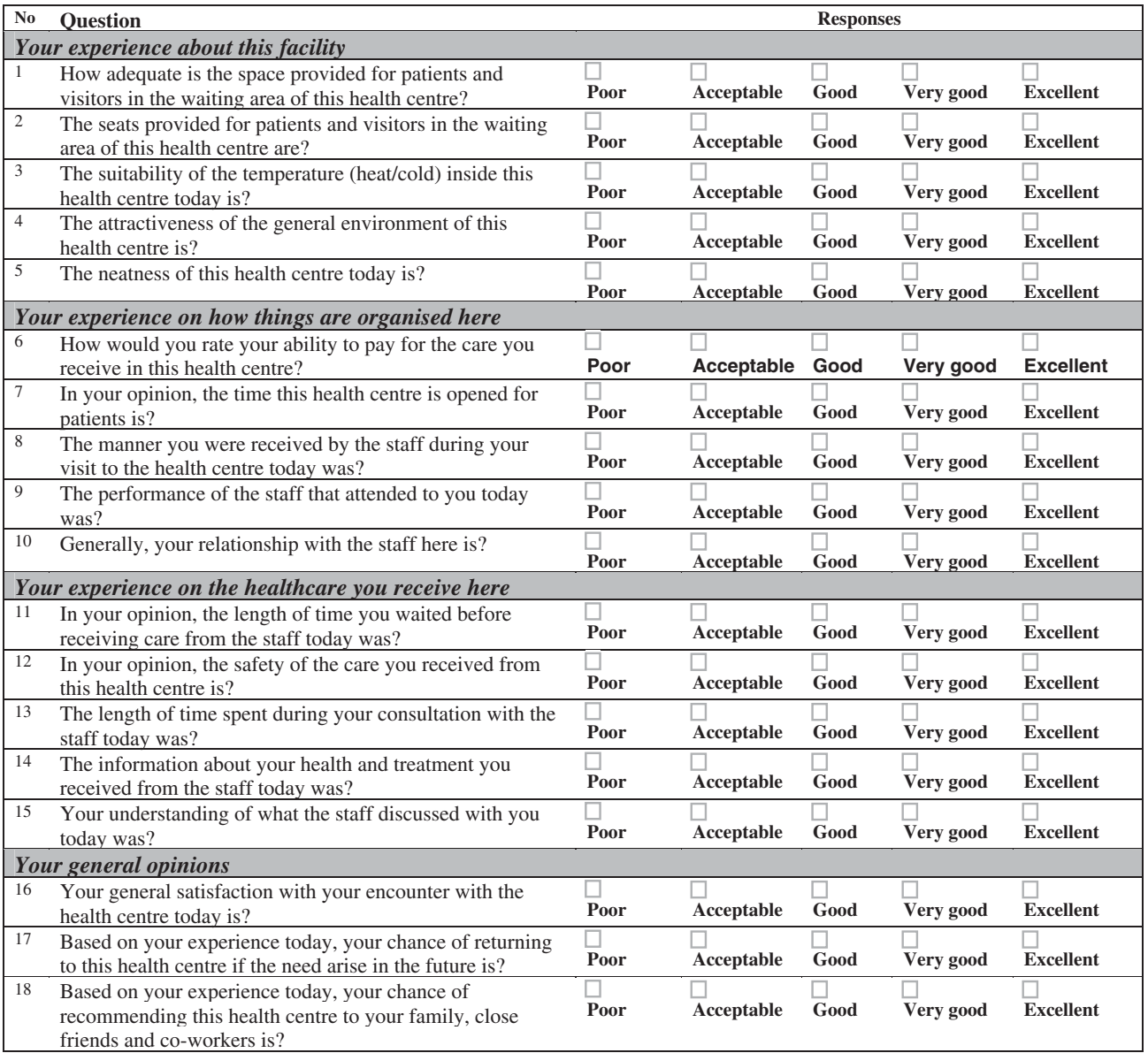




\section{Daprim S. Ogaji et al.}

\section{Core items in the full Patient Evaluation Scale (PES)}

\begin{tabular}{|c|c|c|c|c|c|c|}
\hline No & Questions & & & Response & & \\
\hline 1 & $\begin{array}{l}\text { In your recent visits, how would you rate the availability } \\
\text { of light (from public power or generator) in the health } \\
\text { centre? }\end{array}$ & $\begin{array}{l} \\
\text { Poor }\end{array}$ & $\square_{\text {Acceptable }}$ & $\square_{\text {Good }}$ & $\begin{array}{l}\square \\
\text { Very good }\end{array}$ & $\square_{\text {Excellent }}$ \\
\hline 2 & $\begin{array}{l}\text { In your recent visits, how would you rate the availability } \\
\text { of water in the health centre? }\end{array}$ & $\begin{array}{ll}\square \\
\text { Poor }\end{array}$ & $\begin{array}{ll}\square \\
\text { Acceptable }\end{array}$ & $\begin{array}{ll}\square \\
\text { Good } \\
\end{array}$ & $\begin{array}{l}\square \\
\text { Very good }\end{array}$ & $\begin{array}{ll}\square \\
\text { Excellent } \\
\end{array}$ \\
\hline 3 & $\begin{array}{l}\text { How adequate is the space provided for patients and } \\
\text { visitors in the waiting area of this health centre? }\end{array}$ & $\begin{array}{ll} \\
\text { Poor }\end{array}$ & Acceptable & $\begin{array}{l}\text { Good } \\
\end{array}$ & $\square$ Very good & $\begin{array}{l} \\
\text { Excellent } \\
\end{array}$ \\
\hline 4 & $\begin{array}{l}\text { The seats provided for patients and visitors in the waiting } \\
\text { area of this health centre are? }\end{array}$ & $\begin{array}{ll}\square \\
\text { Poor }\end{array}$ & Acceptable & $\square$ & $\square$ Very good & $\begin{array}{l} \\
\text { Excellent }\end{array}$ \\
\hline 5 & $\begin{array}{l}\text { The suitability of the temperature (heat/cold) inside this } \\
\text { health centre today is? }\end{array}$ & $\begin{array}{l}\square \\
\text { Poor } \\
\end{array}$ & $\begin{array}{l}\text { Acceptable } \\
\end{array}$ & $\begin{array}{ll}\square \\
\text { Good } \\
\end{array}$ & $\begin{array}{l}\text { Very good } \\
\end{array}$ & $\begin{array}{l}\square \\
\text { Excellent } \\
\end{array}$ \\
\hline 6 & $\begin{array}{l}\text { The attractiveness of the general environment of this } \\
\text { health centre is? }\end{array}$ & $\begin{array}{l}\square \\
\text { Poor }\end{array}$ & Acceptable & Good & $\begin{array}{l}\text { Very good } \\
\end{array}$ & $\begin{array}{l}\text { Excellent } \\
\end{array}$ \\
\hline 7 & The neatness of this health centre today is? & $\begin{array}{ll}\square \\
\text { Poor } \\
\end{array}$ & $\begin{array}{l}\text { Acceptable } \\
\end{array}$ & Good & Very good & Excellent \\
\hline 8 & $\begin{array}{l}\text { How long did you spend coming from home to this } \\
\text { health centre today? }\end{array}$ & $\begin{array}{l}\text { Less than } \\
10 \\
\text { minutes }\end{array}$ & $\begin{array}{l}10 \text { to less } \\
\text { than } 30 \\
\text { minute }\end{array}$ & $\begin{array}{l}30 \text { to } \\
\text { less } \\
\text { than } 60 \\
\text { minutes } \\
\end{array}$ & $\begin{array}{l}1 \text { to less } \\
\text { than } 2 \\
\text { hours }\end{array}$ & $\begin{array}{l}\text { More } \\
\text { than } 2 \\
\text { hours }\end{array}$ \\
\hline 9 & $\begin{array}{l}\text { How would you assess your ease of coming down to the } \\
\text { health centre today? }\end{array}$ & $\begin{array}{l}\square \\
\text { Poor }\end{array}$ & Acceptable & $\begin{array}{l}\square \\
\text { Good } \\
\end{array}$ & $\square$ Very good & Excellent \\
\hline 10 & $\begin{array}{l}\text { How would you assess your chance of meeting staff } \\
\text { whenever you come to this health centre? }\end{array}$ & $\begin{array}{l}\square \\
\text { Poor }\end{array}$ & Acceptable & $\begin{array}{l}\text { Good } \\
\end{array}$ & $\square$ Very good & $\begin{array}{l}\text { Excellent } \\
\end{array}$ \\
\hline 11 & $\begin{array}{l}\text { How would you rate your ability to pay for the care you } \\
\text { receive in this health centre? }\end{array}$ & $\begin{array}{l} \\
\text { Poor } \\
\end{array}$ & Acceptable & $\begin{array}{l}\text { Good } \\
\end{array}$ & $\square$ & $\begin{array}{l}\square \\
\text { Excellent } \\
\end{array}$ \\
\hline 12 & $\begin{array}{l}\text { In your opinion, the time this health centre is opened for } \\
\text { patients is? }\end{array}$ & $\begin{array}{ll}\square \\
\text { Poor }\end{array}$ & Acceptable & $\square$ & $\square$ Very good & Excellent \\
\hline 13 & $\begin{array}{l}\text { The manner you were received by the staff during your } \\
\text { visit to the health centre today was? }\end{array}$ & $\begin{array}{l}\square \\
\text { Poor } \\
\end{array}$ & $\begin{array}{l}\square \\
\text { Acceptable }\end{array}$ & $\square$ Good & $\square$ & $\begin{array}{l}\square \\
\text { Excellent } \\
\end{array}$ \\
\hline 14 & $\begin{array}{l}\text { The performance of the staff that attended to you today } \\
\text { was? }\end{array}$ & $\begin{array}{l}\square \\
\text { Poor }\end{array}$ & Acceptable & $\begin{array}{l} \\
\text { Good } \\
\end{array}$ & $\square$ Very good & $\begin{array}{l} \\
\text { Excellent } \\
\end{array}$ \\
\hline 15 & Generally, your relationship with the staff here is? & $\begin{array}{l}\square \\
\text { Poor } \\
\end{array}$ & Acceptable & $\begin{array}{l}\text { Good } \\
\end{array}$ & $\begin{array}{l}\text { Very good } \\
\end{array}$ & Excellent \\
\hline 16 & $\begin{array}{l}\text { How long did you wait in this health centre before you } \\
\text { received care from the staff today? }\end{array}$ & $\begin{array}{l}\text { Less than } \\
10 \\
\text { minutes }\end{array}$ & $\begin{array}{l}10 \text { to less } \\
\text { than } 30 \\
\text { minute }\end{array}$ & $\begin{array}{l}30 \text { to } \\
\text { less } \\
\text { than } 60 \\
\text { minutes } \\
\end{array}$ & $\begin{array}{l}1 \text { to less } \\
\text { than } 2 \\
\text { hours }\end{array}$ & $\begin{array}{l}\text { More } \\
\text { than } 2 \\
\text { hours }\end{array}$ \\
\hline 17 & $\begin{array}{l}\text { In your opinion, the length of time you waited before } \\
\text { receiving care from the staff today was? }\end{array}$ & $\begin{array}{ll}\square \\
\text { Poor }\end{array}$ & $\begin{array}{l}\text { Acceptable } \\
\end{array}$ & $\begin{array}{ll}\text { Good } \\
\end{array}$ & Very good & $\begin{array}{l}\text { Excellent } \\
\end{array}$ \\
\hline 18 & $\begin{array}{l}\text { In your opinion, the safety of the care you received from } \\
\text { this health centre is? }\end{array}$ & $\begin{array}{l}\square \\
\text { Poor }\end{array}$ & Acceptable & $\square_{\text {Good }}$ & $\square$ Very good & $\square_{\text {Excellent }}$ \\
\hline 19 & $\begin{array}{l}\text { The length of time spent during your consultation with } \\
\text { the staff today was? }\end{array}$ & $\begin{array}{l}\square \\
\text { Poor }\end{array}$ & $\begin{array}{l}\square \\
\text { Acceptable }\end{array}$ & $\square$ & $\square$ Very good & $\begin{array}{l}\square \\
\text { Excellent } \\
\end{array}$ \\
\hline 20 & $\begin{array}{l}\text { The information about your health and treatment you } \\
\text { received from the staff today was? }\end{array}$ & $\begin{array}{l}\square \\
\text { Poor }\end{array}$ & Acceptable & $\begin{array}{l}\text { Good } \\
\end{array}$ & $\square$ Very good & $\begin{array}{l}\square \\
\text { Excellent }\end{array}$ \\
\hline 21 & $\begin{array}{l}\text { Your understanding of what the staff discussed with you } \\
\text { today was? }\end{array}$ & $\begin{array}{ll}\square \\
\text { Poor }\end{array}$ & Acceptable & $\begin{array}{l}\text { Good } \\
\end{array}$ & $\square$ Very good & Excellent \\
\hline 22 & $\begin{array}{l}\text { In your opinion, the order people are given attention in } \\
\text { relation to when they came to the health centre is? }\end{array}$ & $\begin{array}{l}\square \\
\text { Poor } \\
\end{array}$ & Acceptable & $\begin{array}{ll}\text { Good } \\
\end{array}$ & Very good & $\begin{array}{l}\text { Excellent } \\
\end{array}$ \\
\hline 23 & $\begin{array}{l}\text { What you received (e.g. drugs) from the health centre } \\
\text { today was? }\end{array}$ & $\begin{array}{ll}\square \\
\text { Poor }\end{array}$ & Acceptable & $\square_{\text {Good }}$ & $\square$ Very good & Excellent \\
\hline 24 & $\begin{array}{l}\text { The improvement in your health condition after your last } \\
\text { visit to this health centre was? }\end{array}$ & $\square_{\text {Poor }}$ & $\square$ Acceptable & $\square$ Good & $\square$ Very good & $\square$ Excellent \\
\hline 25 & $\begin{array}{l}\text { Your general satisfaction with your encounter with the } \\
\text { health centre today is? }\end{array}$ & $\square_{\text {Poor }}$ & $\square_{\text {Acceptable }}$ & $\square_{\text {Good }}$ & $\nabla_{\text {Very good }}$ & $\square_{\text {Excellent }}$ \\
\hline 26 & $\begin{array}{l}\text { Based on your experience today, your chance of } \\
\text { returning to this health centre if the need arise in the } \\
\text { future is? }\end{array}$ & $\begin{array}{l}\square \\
\text { Poor }\end{array}$ & $\begin{array}{l}\square \\
\text { Acceptable }\end{array}$ & $\square_{\text {Good }}$ & $\begin{array}{l} \\
\text { Very good }\end{array}$ & $\begin{array}{l}\square \\
\text { Excellent }\end{array}$ \\
\hline 27 & $\begin{array}{l}\text { Based on your experience today, your chance of } \\
\text { recommending this health centre to your family, close } \\
\text { friends and co-workers is? }\end{array}$ & $\begin{array}{l}\square \\
\text { Poor }\end{array}$ & $\begin{array}{l}\square \\
\text { Acceptable }\end{array}$ & $\square$ & $\square$ & $\begin{array}{l}\square \\
\text { Excellent }\end{array}$ \\
\hline
\end{tabular}

Primary Health Care Research \& Development 2017; 18: 161-182 